Ethiopian Journal of Environmental Studies \& Management 8(2): 196 - 205, 2015.

ISSN:1998-0507

doi: http://dx.doi.org/10.4314/ejesm.v8i2.9

Submitted: December 16, 2014

Accepted: February 16, 2016

\title{
ASSESSMENT OF THE EFFECT OF URBAN INFRASTRUCTURE AS A TOOL FOR ENHANCING THE VALUES OF RESIDENTIAL PROPERTY IN AKURE
}

\author{
NWOSU, A.E. \\ Department of Estate Management, Federal University of Technology, Akure, Ondo State \\ Email: nwosuaku@yahoo.com
}

\begin{abstract}
The study is aimed at investigating the effect of urban infrastructure as a tool for enhancing residential property values in Isolo/Araromi/Odokoyi and Irowo/Odige/Odopetu in Akure. The sampling frame of the houses in the study area was 412 and 405 respectively. However, Kothari formula was used to arrive at a sample size of 280 in Isolo/Araromi/Odokoyi and 289 Irowo/Odige/Odopetu for the study. Questionnaires were administered on occupants of residential properties in the study area to elicit information. Out of the 559 questionnaires administered 443 were duly filled and returned for analysis. The information collected was analyzed using descriptive statistics and Multiple Regression. The result reveals that the $R^{2}$ statistic (0.819) for Irowo/Odige/Odopetu indicates that the independent variables account for $81.9 \%$ of rental value. Also, the $R^{2}(0.781)$ for Isolo/Araromi/Odokoyi is 0.781 which implies that the independent variables account for $78.1 \%$ of the rental values The study therefore recommends that the state government should put in place the necessary infrastructure in Isolo/Araromi/Odokoyi so as to enhance the residential property values. Also, the state government should enlighten the people on the need for maintenance culture.
\end{abstract}

Key Words: Sustainability, Urban Infrastructure, Residential and Property Values

\section{Introduction}

Housing has been universally accepted as a basic essential human need that comes only after food and clothing. Housing in all its ramifications is more than a mere shelter since it embraces all the social services and utilities that make a community or neighbourhood a livable environment (Adedeji et al., 2010). The fact remains that unlike food and clothing, real property is difficult to acquire. Its importance can be seen in the vital roles it plays in socioeconomic and psychological development of individuals, states and nations (Ibrahim, 2011). Man is a socio-economic being seeking to dwell in residential units that provide him the maximum supply of the necessary facilities. Perhaps, one of the major challenges of successive government in Nigeria is the possibility of making cities good places and providing basic urban services and necessary facilities for its growing population (Adewusi and Akinbogun, 2010 and Olujimi, 2010). Unfortunately, the level of deficiencies and the degree of urban infrastructure in Nigeria urban centre is worrisome due to the inability of the government to meet up with the social needs of the people at large, because the instrument capable of positioning the cities and towns as an 
economic base is the functional urban infrastructure.

The efficiency of any form of human activity system largely depends on the provision of the efficient infrastructural facilities and services (Adebayo, 2006 and Babarinde, 1998). The Urban infrastructure covers a wide range of services and facilities, namely electricity, water, roads, waste disposal, drainage, hospital, schools etc. Where urban infrastructure is adequately provided and efficiently managed, productive and profitable land uses are usually attracted towards such area and usually results in an increase in land and housing values, either sales or rentals (Harvey, 1994). Rental values of properties vary from place to place depending on various factors among which facilities availability stand prominent. Location, quality of building, demand and supply rate and the environmental characteristics of the area are some of the factors affecting rental values of residential properties. According to Hammer et al. (2000), provision of good and adequate infrastructure is central to property values. Availability and state of infrastructure provision come into play to enhance property values while areas that experience deficiencies command lower property values.

According to Adewusi and Akinbogun (2010), the assessment of property values depends on the property's unique characteristics, each of which provides utilities or disutility to individuals. These characteristics are generally classified into external (like road network, electricity, water supply, health facilities among others) and internal (design, size, age, etc) infrastructure. The urban infrastructural decay such as poor road network, lack of portable water supply, bad drainages and canals, poor housing and poor waste management system have increased the environmental threat within the urban populace (Gbadegesin and Aluko, 2010). On the other hand, depreciation may occur in property values due to infrastructural degradation and negative changes in neighbourhood properties. Where urban infrastructure is adequately provided and efficiently managed, productive and profitable land uses are usually attracted towards such area (Harvey, 1993). This competition for location with good urban infrastructure usually results in an increase in land values. Adequacy of infrastructural facilities in a location will add both social and economic values to the land in such area and prospective buyers will be willing to pay more for land located in areas where there are adequate infrastructural facilities (Nwosu, 2004).

According to Hammer et al. (2000), provision of good and adequate infrastructure is central to property values. A residential user may be willing to pay a high value for a property depending on his consideration for basic facilities such as accessibility, water and electricity (Harvey, 1993). Litchfield (1974) also observed that areas with basic facilities such as access roads, good drainage, electricity, public water supply and hospitals would attract high property values.

Adebayo (2006) used descriptive analysis to study the state of urban infrastructure and its effect on property values in Lagos, the study reveals that the presence of essential infrastructural facilities and services serve as major determinant of property values. The property values tend to peak in those areas that enjoy easy accessibility (through road network), electricity, pipe borne water and efficient drainage system. In contrast, the low rate of rental values in some areas can be adduced to the poor state of the infrastructural facilities. Olujimi (2010) used multiple regression models to study the relationship of infrastructural facilities 
in the determination of rental values of residential property in Akure. The study reveals that wall-fence and installed burglary proof are significant determinants of rental values of residential properties in Akure. Olujimi and Bello (2009) studied the effects of infrastructural facilities on the rental values of residential property using Multiple Regression and the study reveals that infrastructural facilities contributed $30.50 \%$ in the determination of rental values of residential buildings in Akure. Adewusi and Akinbogun (2010) studied infrastructure development for sustainable economic growth in Nigeria using descriptive statistics. The study reveals that property value in the study area has continued to increase despite the deplorable condition of some infrastructural facilities. In general, increase in residential properties values are associated with the provision of adequate infrastructural facilities put in place for the occupiers to have access to. Facilities like electricity, waste disposal, road network, drainage, schools, streetlight, security etc add great value to an area and the demand for rental residential property. Ibrahim (2011) studied infrastructural facilities and their effect on rental values of residential properties in Ilorin metropolis using descriptive statistics and the study reveals that presence of facilities generates high preference, keen competition for properties and thus high rental values, while absence of facilities results in low patronage, disincentive to people, attraction of poor tenant and consequently low rental values.

Therefore, this paper assesses the adequacy of urban infrastructure and their effect on the values of residential property in Akure.

\section{Study Area}

Akure is a traditional city and like other Yoruba towns in the south western part of the country. It lies approximately on latitude $7^{\circ} 15^{\prime}$ North of the Equator and longitude $5^{\circ} 15^{\prime}$ East of the Greenwich meridian. Akure is the capital of Ondo state which was created on $3^{\text {rd }}$ of February, 1976. Consequently, heterogeneous activities have since characterized the town; it has cluster area of economic activities such as Oja-Oba, Oke-Aro, Eyinke, Irowo, Odige, Odopetu, Ondo road, Isolo, Araromi, Odokoyi etc. The estimated population of Akure in 1996 was 269,207 (National Population Commission, 1996) and 353,211 with male 175,495 and female 177,716 in 2006 (National Population Commission, 2006). Akure city is comprised of many communities of which Irowo/Odige/Odopetu and Isolo/Araromi/Odokoyi are part. Irowo/Odige/Odopetu community is bounded in the North by Arakale Road, in the East by Hospital Road, in the West by Irowo Street and in the South by Hospital road. Isolo/Araromi/Odokoyi community, however, is bounded in the North by IleshaAkure-Owo-Benin Express, in the East by Ijomu/oke-Ijebu Quarters in the West by Odo-Ijoka/Owode and in the South by ObaAdesida road. The population of Irowo/Odige/Odopetu community is 54,730 and that of Isolo/Araromi/Odokoyi is 58,987 (Ondo State Planning Report, 2006). The number of houses is 405 for Irowo/ Odige/ Odopetu and 412 Isolo/Araromi/Odokoyi communities (Ondo State Planning Report, 2008). The communities were chosen for this study because Irowo/Odige/Odopetu community presently has experienced upgrading of urban infrastructure in recent times while Isolo/Aroromi/Odokoyi area still suffer deficiencies of urban infrastructure and was used as basis for comparison because it is in the urban center but has not experienced any upgrading of urban infrastructure. 


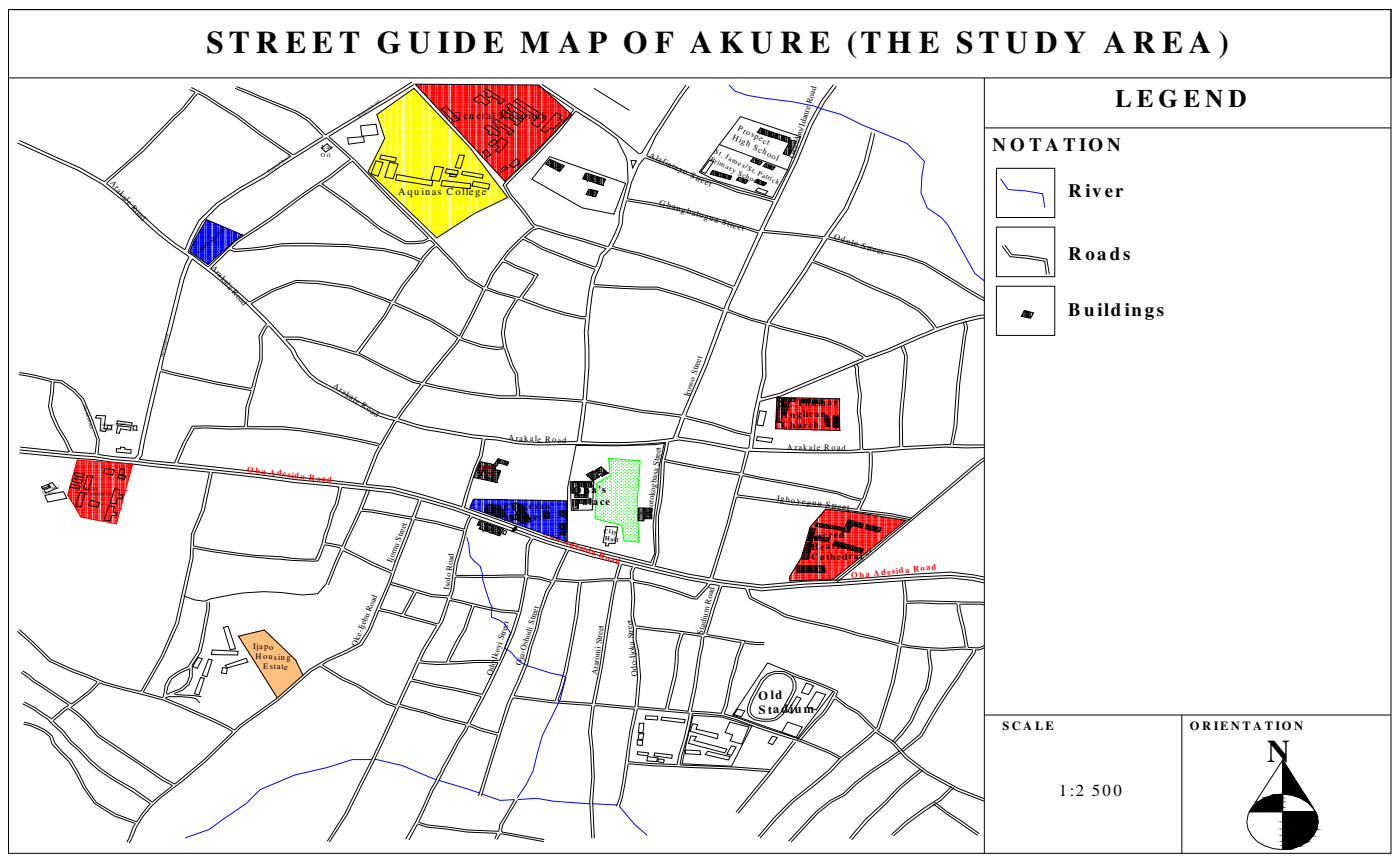

Source: Ondo State Planning Report, 2006

\section{Research Methodology}

The data for the study was collected from selected residents in Irowo/Odige/Odopetu and Isolo/Araromi/Odokoyi communities in Akure. The sampling frame of the houses in the communities is 412 for Isolo/Araromi/Odokoyi and Irowo/Odige/Odopetu is 405 (Ondo State Planning Report, 2006). However, with the use of Kothari (2004) formula as adopted by Bello (2009) and also adopted for this study, the calculation of the sample size was made easier. The sample size for the houses in the communities is 289 for Irowo/ Odige/Odopetu and 280 for Isolo/Araromi/Odokoyi.

Estimation of Sample Size using Kothari (2004) formula is given as:

$$
\mathbf{n}=\frac{Z^{2} \cdot p \cdot q \cdot N}{e^{2}(N-1)+Z^{2} \cdot p \cdot q}
$$

Where, $\mathbf{n}=$ sample size

$$
\mathbf{z}=\text { value of standard deviation at a }
$$
confidence level taken from table of normal curve at variants (z) for $95 \%$ confidence, which is 1.96

$\mathbf{p}=$ sample proportion $(\mathbf{q}=\mathbf{1 - p})$ which in this study is taken as $30 \%(0.3)$

$\mathbf{N}$ = size of house from sample frame of the two communities are 405, (Irowo/Odige/Odopetu) and 412 (Isolo/Aroromi/Odokoyi) in the study.

$\mathbf{e}=$ acceptable error at $3 \%(0.03)$ in this study.

Questionnaires were administered to occupants of residential properties in the neighbourhoods to elicit information. Systematic random sampling technique was used as it is convenient for the study. It affords the opportunity of picking every $3^{\text {rd }}$ house on a street. Out of five hundred and fifty nine questionnaires administered on occupants in the two neighbourhoods, only four hundred and forty three were duly filled and returned for analysis. The mean 
score was used to analyze the adequacy of the urban infrastructure in the study area. This is done on a 5-point Likert scale with a view to estimating the mean score, where numerical values are assigned to respondents rating.

For the purpose of this study, mean score is determined as follows:

Mean score $=\frac{5 n_{g_{3}}+4 n_{4}+3 n_{3}+2 n_{2}+1 n_{1}}{N}$ (2)

However, the multiple linear regressions were used to estimate the effect of urban infrastructure on residential property values in the two communities

(Irowo/Odige/Odopetuand

Isolo/Aroromi/Odokoyi). The form of the regression function used is

RENTV $=\mathrm{b}_{0} \quad+\mathrm{b}_{1}$ ELEC $+\mathrm{b}_{2}$ WATR $\quad+$ $\mathrm{b}_{3} \mathrm{ROADNT}+\mathrm{b}_{4}$ DRAINF $+\mathrm{b}_{5} \mathrm{WASDP}+$ $\mathrm{b}_{6}$ PACKSP $+\mathrm{b}_{7}$ STREETL $+\mathrm{b}_{8}$ SECTY + $\mu$

Where

$b_{0}-b_{8}=$ Regression coefficient for the variables

$\mu=$ error term

\section{Results and Discussion}

Table 1: Adequacy of Urban Infrastructure in the Study Areas

\begin{tabular}{llllc}
\hline & \multicolumn{2}{l}{ Irowo/Odige/Odopetu } & \multicolumn{2}{l}{ Isolo/Aroromi/Odokoyi } \\
\hline INFRASTRUCTURE & MEAN & RANK & MEAN & RANK \\
Electricity & 3.64 & 3 & 2.93 & 2 \\
Water & 3.02 & 6 & 2.85 & 3 \\
Road & 4.11 & 2 & 1.76 & 7 \\
Drainage & 4.21 & 1 & 1.81 & 6 \\
Waste disposal dumps & 3.30 & 5 & 3.14 & 1 \\
Parking space & 1.62 & 8 & 2.18 & 5 \\
Street light & 3.47 & 4 & 1.63 & 8 \\
Security & 2.82 & 7 & 2.60 & 4 \\
Total & 225 & & 217 & \\
\hline
\end{tabular}

Table 1 above shows the mean score and ranking of the respondents view on the adequacy of urban infrastructure provided in the areas. This was done in order to identify which of these urban infrastructures is adequate for the residents of the community. It can be seen from Table 1 which shows that Irowo/Odige/Odopetu has a mean score of 3.64 for electricity while Isolo/Araromi/Odokoyi has a mean score of 2.93. However, the mean scores for the two neighbourhoods are relatively good enough as it ranked third among the facilities for the two communities. Also, the mean score for water in the two communities are 3.02 and 2.85 for Irowo/Odige/Odopetuand
Isolo/Araromi/Odokoyi. The table shows that mean score of road for Irowo/Odige/Odopetuis good as it ranked second while Isolo/Araromi/Odokoyi is very bad as it ranked seven among the facilities this is in conformity with the findings of Fadamiro (2002) that some buildings in Isolo/Araromi/Odokoyi are not accessible by roads. Also, the table shows that Irowo/Odige/Odopetu and Isolo/Araromi/Odokoyi mean score of 4.21 and 1.81 for drainage it is obvious that the mean score for Irowo/Odige/Odopetu is very good as it ranked first among the facilities and Isolo/Araromi/Odokoyi very bad as it ranked six. These findings implies that property in Isolo/Araromi/Odokoyi are 
prone to risk of flooding when there is heavy rain because of insufficient drainage channels particularly from Ala River. From the table above, packing space in the neighbourhoods (Irowo/Odige/Odopetu and Isolo/Araromi/Odokoyi) are 1.62 and 2.18. However, the mean score for two communities are bad as it ranked eight for Irowo/Odige/Odopetuand fifth Isolo/Araromi/Odokoyi. This shows that packing space facility is relatively bad. In summary, the road, drainage, electricity and waste disposal are good in Irowo/Odige/Odopetu, while drainage, road and street light are very bad in Isolo/Araromi/Odokoyi. This result is not contrary to the expectation as Adebayo (2006) noted the deplorable conditions of electricity, water, roads and drainage system in so many parts of the urban areas.

Table 2: Model Summary in Irowo/Odige/Odopetu.

\begin{tabular}{lllll}
\hline Model & R & R Square & Adjusted R Square & Std. Error of the Estimate \\
\hline & $.905^{\text {a }}$ & .819 & .809 & 8161.828 \\
\hline
\end{tabular}

Table 3: Analysis of Variance (ANOVA) in Irowo/Odige/Odopetu

\begin{tabular}{llllll}
\hline Model & Sum of Squares & Df & Mean Square & F & Sig. \\
\hline Regression & $6.2 \mathrm{E}+010$ & 11 & 5621070880 & 84.381 & $.000^{\mathrm{a}}$ \\
Residual & $1.4 \mathrm{E}+010$ & 205 & 66615428.31 & & \\
Total & $7.5 \mathrm{E}+010$ & 216 & & & \\
\hline
\end{tabular}

The performance of this model in Table 2 and 3 above is good as indicated by $\mathrm{R}^{2}$ statistic (0.819). This implies that $81.9 \%$ of the sample variation in the rental values is attributed to the independent variables. The computed F statistic is 84.341. However, since the value of $\mathrm{F}$ statistic falls within the rejection region, the data thereby signify that at least one of the model coefficients is non-zero order

Table 4: Regression Coefficients in Irowo/Odige/Odopetu

\begin{tabular}{llllll}
\hline Model & \multicolumn{2}{l}{ Unstandardized Coefficients } & $\mathrm{T}$ & Sig. & $\begin{array}{l}\text { Zero Order } \\
\text { Correlation }\end{array}$ \\
\cline { 2 - 3 } & $\mathrm{B}$ & Std Error & & & \\
(Constant) & 95436.648 & 3980.579 & 23.976 & .000 & \\
ELEC & 1983.505 & 1703.053 & 1.165 & .246 & -.790 \\
WATR & -8317.558 & 2051.714 & -4.054 & $.000^{* *}$ & -.869 \\
ROADNT & -7130.770 & 2841.017 & -2.510 & $.013^{* *}$ & -.862 \\
DRAINF & -3001.341 & 2668.919 & -1.125 & $.002^{* *}$ & -.833 \\
WASDP & 4582.904 & 1979.819 & 2.315 & $.022^{* *}$ & -.833 \\
PARKSP & -1746.702 & 2255.780 & -.774 & $.004^{* *}$ & -.647 \\
STREETL & -5951.920 & 2973.930 & -2.001 & $.047^{* *}$ & -.859 \\
SECTY & 1234.252 & 1723.171 & .716 & .475 & -.807 \\
\hline SIgnicant & & & & & \\
\hline
\end{tabular}

Significant at $0.05 * *$ denotes significant

Table 4 above shows that six of the variables are significant. These variables are Water (WATR), road network (ROADNT), drainage (DRAINF), waste disposal (WASDP), parking space (PARKSP), and security (SECTY). This may be because of the fact that tenants value 
water, road, drainage, parking space, streetlight, and security when renting an apartment and they are ready to offer an increased rent for apartment where such infrastructural facilities are provided, while electricity (ELEC) is not significant). One may wonder why electricity facilities do not maintain significant relationship with rental value. This might be connected with the poor situation of electricity and the sharing of meters in most tenement buildings in the community.

Table 5: Model Summary in Isolo/Araromi/Odokoyi

\begin{tabular}{lllll}
\hline Model & $\mathrm{R}$ & R Square & Adjusted R Square & Std. Error of the Estimate \\
\hline & $.884^{\mathrm{a}}$ & .781 & .770 & 6439.804 \\
\hline
\end{tabular}

Table 6: Analysis of Variance (ANOVA) in Isolo/Araromi/Odokoyi

\begin{tabular}{llllll}
\hline Model & Sum of Squares & Df & Mean Square & F & Sig. \\
\hline Regression & $3.2 \mathrm{E}+010$ & 11 & 2865441088 & 69.095 & $.000^{\mathrm{a}}$ \\
Residual & $8.8 \mathrm{E}+009$ & 213 & 41471072.45 & & \\
Total & $4.0 \mathrm{E}+010$ & 224 & & & \\
\hline
\end{tabular}

The performance of the model in table 5 and 6 is good as indicated by $\mathrm{R}^{2}$ statistic (.781). This implies that $78.1 \%$ of the sample variation in the rental value is attributed to the independent variables. The computed $\mathrm{F}$ statistic (69.095) falls within the rejection region. The data provides strong evidence that at least one of the model coefficients is non zero and hence the model appears to be useful for predicting rental values in Isolo.

Table 7: Regression Coefficients in Isolo/Araromi/Odokoyi

\begin{tabular}{llllll}
\hline Model & \multicolumn{2}{l}{ Unstandardized Coefficients } & $\mathrm{T}$ & Sig. & $\begin{array}{l}\text { Zero Order } \\
\text { Correlation }\end{array}$ \\
\cline { 2 - 3 } (Constant) & $\mathrm{B}$ & Std Error & & & \\
ELEC & 58278.733 & 1610.409 & 36.189 & .000 & \\
WATR & -5956.591 & 1708.750 & -3.486 & $001 * *$ & -.804 \\
ROADNT & 1861.915 & 1479.721 & 1.258 & .210 & -.754 \\
DRAINF & -4061.008 & 2202.779 & -1.844 & .067 & -.647 \\
WASDP & 1428.599 & 1798.374 & .794 & .428 & -.650 \\
PARKSP & -1590.319 & 1651.946 & -.963 & .337 & -.845 \\
STREETL & 2155.673 & 1497.911 & 1.439 & .152 & -.718 \\
SECTY & 6801.391 & 1363.026 & 4.990 & $.000 * *$ & -.520 \\
\hline
\end{tabular}

Significant at $0.05 * *$ denotes significant

The model in Table 7 shows that two of the variables electricity (ELEC) and street light (STREETL) are significant in Isolo/Araromi/Odokoyi while water (WATR), road (ROADNT), drainage (DRAINF), waste disposal (WASDP), and parking space (PACKSP) is not significant. The relationship between the variables that are not significant is that they have negative influence on the dependent variable (rental value). Perhaps the occupiers consider these variables very paramount when renting an apartment. 
Assessment of the Effect of Urban Infrastructure as a Tool.................NWOSU, A.E.

Table 8: Time Series and Index Growth Rate of Tenement and 3 Bedroom Apartments in the Study Area

\begin{tabular}{|c|c|c|c|c|c|c|c|c|}
\hline \multirow[t]{2}{*}{ Year } & \multicolumn{4}{|c|}{ Irowo/Odige/Odopetu } & \multicolumn{4}{|c|}{ Isolo/Araromi/Odokoyi } \\
\hline & \multicolumn{2}{|c|}{ Tenement Index } & \multicolumn{2}{|c|}{ 3Bedroom Flat Index } & \multicolumn{2}{|c|}{ Tenement Index } & \multicolumn{2}{|c|}{ 3Bedroom Flat Index } \\
\hline 2000 & 6000 & 1.000 & 18000 & 1.000 & 4800 & 1.000 & 18000 & 1.000 \\
\hline 2001 & 6000 & 1.000 & 18000 & 1.000 & 6000 & 1.250 & 18000 & 1.000 \\
\hline 2002 & 7200 & 1.200 & 24000 & 1.333 & 6000 & 1.000 & 24000 & 1.333 \\
\hline & 8400 & 1.167 & 24000 & 1.000 & 7200 & 1.200 & 24000 & 1.000 \\
\hline 2003 & 9500 & 1.131 & 36000 & 1.500 & 7200 & 1.000 & 36000 & 1.500 \\
\hline 2004 & 12000 & 1.263 & 36000 & 1.000 & 7200 & 1.000 & 36000 & 1.000 \\
\hline 2005 & 12800 & 1.067 & 51300 & 1.333 & 7200 & 1.000 & 36000 & 1.000 \\
\hline & 18000 & 1.406 & 73500 & 1.531 & 8400 & 1.167 & 36000 & 1.000 \\
\hline 2006 & 19125 & 1.063 & 89000 & 1.211 & 8400 & 1.000 & 42000 & 1.167 \\
\hline 2007 & 24000 & 1.255 & 97500 & 1.096 & 12000 & 1.500 & 42000 & 1.000 \\
\hline 2008 & & & & & & & & \\
\hline 2009 & & & & & & & & \\
\hline
\end{tabular}

The time series analysis reveals that between the years 2000-2001 the rents passing on the residential property in the areas were relatively stable. In year 20022004 there was a slight increase in the residential property values. The reason could be from the normal rent increase by the landlords. In the same vain in year 2005-2006 there was also a slight increase. There was a sharp increase in rental values in Irowo/Odige/Odopetu between the periods of 2007-2009. This is expected as the areas witnessed infrastructural development and urban renewal through rehabilitation/upgrading by the World Bank project undertaken by the State Government. Such improvement and rehabilitation scheme included the construction of drainage, tarring of roads, water provision, schools, electrification projects through installation of electric transformers, street light and waste disposal systems. On the other hand Isolo/Araromi/Odokoyi area attracted lower rental values since the area is characterized by old fashioned infrastructure in the form of poor road network, poor drainage, overcrowding, high occupancy ratio and dilapidated structures.

\section{Recommendations and Conclusion}

The paper has examined the impact of urban infrastructure as a tool for enhancing the values of residential property in Akure. It was revealed that rent paid for different residential apartment in Irowo/Odige/Odopetu have continued to increase from the periods of 2007-2009 as at when the survey was carry out because of the rehabilitation of some infrastructures and the provision of some that are not available at all and Isolo/Araromi/Odokoyi maintained a steady growth rate because of the deplorable condition of the urban infrastructures. The study further discovered that the demand pressure for properties contributed to rent increase because of the urban infrastructures they are enjoying in Irowo/Odige/Odopetu. The paper therefore makes the following recommendations:

The widely held view that Government should handle the provision of urban infrastructure despite obvious weaknesses of the public sector should be discouraged. The assistance of international bodies like the United Nation Children Environmental Funds, Centre for Human Settlement (HABITAT) and the Millennium Development Goals would be needed for 
effective and enduring urban infrastructural provision in the study areas. Government should embark on comprehensive rehabilitation of infrastructural facilities in the Isolo/Araromi/ Odokoyi and other areas that need same. Also, the people need enlightenment on the importance and management of these infrastructural facilities. This is needful so as to sustain every improvement put in place.

\section{References}

Adebayo, M. (2006). The State of Urban Infrastructure and its Effects on Property Values in Lagos, Nigeria. Journal of land use Development studies, 2(1): 50-59.

Adedeji, Y, Aluko, O. and Ogunsote, O. (2010). Sustainable Landscaping and Green Housing in Tropical Climates. Conference proceeding of the First International Conference of the School of Environmental Technology, Federal University of Technology Akure, 1(1): 204-214.

Adewusi, O. and Akinbogun, S. (2010). Infrastructure Development for Sustainable Economic Growth in Nigeria. Conference proceeding of the First International Conference of the School of Environmental Technology, Federal University of Technology Akure, 1(1) 159-163.

Aribigbola, A. (2008). Housing Policy Formulation in Developing Countries: Evidence of Programme Implementation for Akure, Ondo State, Nigeria. Journal of Humanities and Ecology, 23 (2), 125 - 134.

Babarinde, J. (1998). Analysis of Industrial relocation to Housing and Infrastructural services in the Metropolitan Lagos' The Lagos Journal of Environmental Studies 1(1): $97-108$
Bello, I. (2007). Infrastructural Development, as a Panacea to Sustainable Reforms in Nigeria Polytechnic. Paper presented at the $2^{\text {nd }}$ National Conference on Technology for sustainable development, Federal Polytechnic, Ilaro, Ogun State.

Bello, V.A. (2009). Effect of Hazardous Waste on Property Value. PhD Thesis, Department of Estate Management, Federal University of Technology, Akure, Nigeria.

Britton, W., Davies, K. and Johnson, T (1998). Modern Methods of valuation ( $8^{\text {th }}$ ed.) London. The Estate Gazette.

DFID (2005). Nigeria by Number, International Development Magazines, 3: 8-9.

Donald, C.S. (1974). Professional Education in Public Works/Environmental Engineering Administration, $5^{\text {th }}$ edition. Chicago. American Public Works and Associations.

Fox, W. (1994). Strategy Options for Urban Infrastructure Management. Urban Management program Paper 17, the World Bank, Washington D.C, pp7.

Frank, I. (2003). The State of Urban Infrastructure in Nigeria in Yomi Fawomi (ed), Urban Finance and Development Infrastructure in Nigeria. The Institute of Land Economics and Atlantic books Ibadan, Nigeria.

Hammer, L, Booth, D. and Love, H. (2000). Poverty and transport; A Report prepared for the World Bank in collaboration with DFID, Overseas Development Institute.

Harvey, J. (1993). Urban Land Economics $3^{\text {rd }}$ Edition Macmillan Press Limited London.

Ibrahim, T. (2011). A Survey of Infrastructural Facilities and their 
Effects on Rental Values of Residential Properties in Ilorin Metropolis. Journal of Environmental Sciences and Resource Management. 3: 36 - 41.

Iremiren, A. (2001) Impact of the Private Provision of Infrastructural Facilities on housing Cost, B. Tech Project. Federal University of technology, Akure, Department of Estate Management.

Kothari, C. (2004). Research Methodology, Methods and Techniques. Newage International Publishers Limited New Delhi.

Leyi, E., Jelili, M. and Adeyeye, L. (2007). Urban Renewal in Agbola, T. Egunjobi, L and Olatubara, C (eds.) Housing Development and Management, 538-567.

Litchfield, N. (1974). Economics of Planning Development London Estate Gazette Limited.

NPC (1996). National Population Commission, Census 91. Final Results Ondo State.

Nubi, T.O. (2003). Procuring, Managing and Financing Urban Infrastructure. Towards an Integrated Approach, Land Management and Property Tax Reform in Nigeria in Omirin et al (ed) Department of Estate Management, University of Lagos, Akoka.
Nwosu, A (2004). The Nature and Effects of Urban Decay on Property Values. B.Sc Thesis, Department of Estate Management, Imo State University.

Obateru, O. (2003). Land Subdivision Basics. Visionary Publication, Ibadan Nigeria.

Olujimi, J. (2010). Analysis of the Relationship of Infrastructural Facilities in the Determination of Rental Values of Residential Properties in Akure, Nigeria. Journal of Act and Social Sciences Volume 10 Olujimi, J. and Bello, M. (2009). Effects of Infrastructural Facilities on Rental Values of Residential Property. Journal of Social Sciences 5(4): 332341.

Ominrin, M. (2003). "Urban Infrastructure Development Problems and Prospect" Proceeding of National Workshop on Land Management and Property Tax Reform in Nigeria, Department of Estate Management, University of Lagos, Nigeria.

Ondo State Planning Report (2006). A Report Submitted to the Millennium Development Goals.

Ondo State Planning Report (2008). A Report Submitted to the Millennium Development Goals. 